\title{
Ideologically-Induced Understatement in \\ English/Arabic News Translation: A Critical Discourse Analysis - Socionarrative Approach
}

\author{
Sama Dawood Salman*
}

\section{Introduction}

The classical definition of ideology is a set of beliefs dominant in a certain community (Hatim \& Mason, 1997). In Critical Discourse Analysis (CDA), however, this term means much more than this. For most CDA scholars, including Thompson (1984); Van Dijk (1993); and Fairclough (2003), ideologies are very much related to power. Fairclough (2003) maintains that ideology is a social theme that is not merely related to attitudes and beliefs, but is also about power and supremacy. He views ideologies as the means through which power is "established, maintained, enacted and transformed" (1995/2010, p. 26). According to Cheng (2012), ideology is very much related to narratives in news articles. They are interrelated and inseparable because ideologies control narratives, while narratives build the dominant ideologies.

Translators, mainly those of news stories, adopt different strategies to get along with the ideologies of their agencies and, sometimes, to manipulate with the source text's suggested narrative. Among these strategies, and the one that this study is focusing on, is understatement. According to Cambridge Dictionary (2017), understatement denotes the use of lexical items to describe something in a way that makes it seem less important, serious or shocking than it is believed to be.

This study investigates the strategy of understatement in the context of English - Arabic news translation. To achieve this end, the lexical choices of both the source text and the target text are analyzed adopting Fairclough's Relational Approach (2003). However, since Fairclough (2003) himself maintains that textual analysis alone is not enough to provide full understanding of ideology, and that there is a need for opening up to other disciplines (2003), the present study benefits from Harding's Socio-narrative Approach (2012) to explore how temporary narrators (i.e. translators) can contribute to a distinct ideology through changing the original narrative.

\footnotetext{
*Assistant Professor, Faculty of Al-Alsun, Misr International University.
} 


\section{Research Questions}

This study hypothesizes that understatement is a framing tool that news writers and translators utilize to promote for different narratives in line with the ideology of the media institutions they represent. Therefore, the translation of news stories and their embedded narrative need to be analyzed intertextually and intratextually within the framework of a transdisciplinary approach. The study attempts to answer the following research questions:

- To what extent can ideology influence the translation of news stories?

- How can the translation strategy of understatement change the original narrative of a given news story?

- How can a transdisciplinary approach be applied to provide a systematic analysis of the narratives?

\section{Understatement in News Translation}

When translating a news story, translators should always bear in mind space and time limitations, in-house style preferences, and, above all, ideological considerations which may all force the translators to re-write the whole story. Van Dijk (2003) points out that ideology in news writing covers a wide range of issues including how news are gathered and covered. He believes that the ideologies of the institutions that news producers represent decide what will be included and mentioned. Fairclough (2003) sheds light on the question of narrativity in making news stories. He believes that news narrators (i.e., journalists) usually impose their narrative on the audience. This is because they interpret and construct events through including certain aspects and excluding others. Darwish (2006) argues that translation of news stories involves "a reframing process" that entails reshaping of events due to the influence of the institutions that translators represent (p. 52). Van Doorslaer (2010) mentions that translating news stories is much more than just finding linguistic equivalence; as it involves ideological considerations. He maintains that translators of news play three main roles: mediators between cultures, decision makers and gatekeepers. Similarly, Chen (2011) likens news translators (i.e. journalists who are transediting news or translators who work with journalists), to "gate-keepers" as they filter out what information should be passed and what other information should be kept out (p. 120). Van Doorslaer (2012) points out that the ongoing confusion between translating and rewriting news stories has led to the emergence of the concept of "journalation," that is, the use of translated material when creating a news story (p. 1046). In the same vein, Schäffner (2012) holds the view that news translation is "a textual and a sociocultural process which involves transformations" (p. 881). The same idea is expressed by Liu (2013) who points out that when transediting, translators of news stories usually adopt 
the frames of the institutions they belong to. Omar (2016) mentions that the ideology of publishers and institutions affect the process of news translation, since they impose their ideology on the translators. Gambier (2016) points out that while translating news, a number of transformations take place, including changing the focus of the source text, omitting or adding parts.

All this implies that news stories can be described as representations of power relations. Fairclough (2003) believes that producing news is about including some parts while excluding others in an attempt to impose a given narrative on the readers, which serves a given ideology. One of the ways that news translators appeal to in their attempt to include/exclude elements of a news story is understatement. According to the Literary Devices website (2017), understatement is defined as a tool utilized by writers "to intentionally make a situation seem less important than it really is." This study attempts to look into the issue of understatement as a translation tool from a CDA-Socionarrative perspective.

\section{Theoretical Framework}

\section{CDA: Fairclough's Relational Approach (2003)}

Van Dijk (1993) notes that Critical Discourse Analysis (CDA) is significant because it explains how language is used to produce/reproduce dominance. Dominant groups use language tools (e.g. lexical elements and structures) to develop certain ideologies in the public mind. Thus, he defines CDA as an analytical research that investigates how "social-power abuse and inequality are enacted, reproduced, legitimated, and resisted by text and talk in the social and political context" (2015, p. 466). Among the scholars who contributed to CDA is Fairclough whose Relational Approach to text analysis is adopted in this study.

Fairclough (2003) distinguishes between two types of relations when it comes to text analysis: the first type is internal relations which refer to semantic, lexical, grammatical and phonological choices. The semantic level is related to the meaning between words, and phrases; the grammatical level has to do with the grammatical units such as morphemes, clauses and sentences; the lexical relations are those related to vocabulary and collocations; and phonological relations are specifically found in spoken language such as intonation and rhyme. Then there are the external relations of a text, which are related to how much of the world it reflects and how it represents that world. Fairclough (2003) believes that the internal textual analysis is a significant part of the external textual analysis, as it helps understand the ideology implied. Fairclough then suggests the term "intertexutality" to refer to incorporating within a given text parts of other texts. Intertextuality could be done indirectly in the form of summary or directly as in reproducing the actual words. This feature quite often 
appears in news since writers, and in most cases translators, tend to include in their stories parts of other texts or voices. These parts could either be in the original language of texts or, as the examples in this study show, in the language these texts are translated into.

In the same book, Fairclough (2003) supports a transdisciplinary approach to the study of texts. He maintains that "dialogue with other disciplines" can help formulating theories and methods of analysis (p. 225). He puts special emphasis on the integration between textual and social analysis, pointing out that textual analysis should not precede social analysis, but the analysis should be "an open process which can be enhanced through dialogue across disciplines" (pp. 15-16). Fairclough sees texts as components of social interaction. To analyze a text, one should also look into such social, non-linguistic elements as body language, the relation between participants, and the social environment. Furthermore, he believes that texts and social events affect one another. The social settings affect how texts are constructed and texts, in turn, can bring about social changes through affecting people's ideology. Such an approach has also been backed by other CDA scholars. Van Dijk (2003) believes that in order to understand the ideologies of a text, one should analyze it within its cultural and social context. Similarly, Wodak and Meyer (2008) argue for analyzing texts from a social perspective as they believe that CDA, by definition, is not about analyzing linguistic units, but rather about examining "social phenomena" (p. 2). This is the main reason why this study tries to benefit from a theoretical approach in Translation Studies that is based on sociology and narratology.

\section{Harding's Socionarraive Theory (2012)}

Since the twenty first century, Narrative Theory has been viewed as a tool for analysis not only in literature but also in various disciplines including history, education, gender studies, and even physics (Harding, 2012). In 2006, Baker in her book Translation and conflict: A narrative account cites examples that show how the Narrative Theory can say a lot about the strategies that translators appeal to while playing their role as cultural mediators. The main focus of Baker's application is the role that translators play during political conflicts. She touches upon how narratives are used by political powers to shape the public perception of events, and upon whether or not translators/interpreters have the right to reframe narratives during conflicts.

Harding (2012) takes Baker's Narrative Theory (2006) as a starting point to develop her application in Translation Studies through mingling between the narrative and the sociological approaches. She believes that the Narrative Theory alone cannot provide detailed textual analysis and that, therefore, there is a need to have it integrated within a sociological approach. The Socio-narrative Theory, 
according to her, is a strong theoretical framework to describe how translation can affect "the construction and reconstruction of narratives" (Harding, 2012, p. 290). Perhaps the most important aspect that Harding adds to Baker's work, and the one that is significant to this study, is that she focuses on the role of narrators (original storytellers) and temporary narrators (translators) who are thought to be contributors to a distinct narrative.

While applying Baker's theory (2006) to online media reportage, Harding classifies narratives into two types: (a) personal narrative; and (b) shared or collective narratives; though they are interconnected and one can hardly draw a clear-cut line between the two. The former are those stories that are created by individuals, whereas the latter are stories that are constructed through circulation among members of a given society. She believes that this typology reflects the fact that individuals in the case of personal narratives are held accountable for the stories they construct about themselves, whereas in the shared/collective narratives, stories are being constructed and circulated among the community either by agreement or force. Under these two main categories, there are local narratives that relate "particular events ... in particular places at particular times" (Harding, 2012, p. 293); societal narratives which are institutions-specific and not for public circulation; theoretical narratives which are relevant to theories and the general use of abstract terms to refer to concrete situations; and meta narratives that refer to our role as individuals in a certain historical period.

Furthermore, Harding (2012) admits that most of her work in this regard is based on Mieke Bal's Narratology: An introduction to the theory of narrative (2009). Bal sees texts as a structured "whole composed of language signs" told by an agent (i.e. narrator) in a particular way (2009, p. 5). In other words, news stories are texts produced by narrators (news agencies) talking about certain events within a certain narrative.

Applying the Socio-narrative Approach to media texts, Harding sees news agencies as narrators and calls the original text the primary narrative which consists of four elements: "events, actors, time and location" (p. 296). These primary narratives can later be contributed to or manipulated by temporary narrators who could be translators, commentators, or correspondents. Harding (2012) states that news translation can provide many examples of how "political conflicts are narrated by, and to, key players" (p. 303). And since aspects of news stories could be manipulated by translators to promote for a different narrative, a text and its translation can share the same elements, yet differ in the way each one represents the events (Harding, 2012).

This study offers an intertextual analysis of texts based on Fairclough's Relational Approach (2003) and an intra-textual one that builds on Harding's Socio-narrative Theory (2012). Such a transdisciplinary analysis can reveal how 
textual components are manipulated or selectively appropriated to contribute to constructing narratives. It is to be noted that the two levels of analysis are interdependent and that, therefore, the analysis is not be carried out sequentially, but rather simultaneously, where one moves backwards and forwards between the two levels.

\section{Methodology}

Fairclough (2003) believes that textual analysis alone is not enough to provide full understanding of all the ideological aspects of texts. Therefore, he calls for opening up to other disciplines, mainly to social research, that can provide deeper insight into the link between texts and social life. It is for this reason that the present study draws on the Socionarrative Approach of Harding (2012) to be a complementary to Fairclough's Relational Approach (2003). The former approach is chosen because it highlights the role of translators as temporary narrators, and relates texts to their social contexts. Fairclough's approach, on the other hand, is selected because it focuses on ideology and offers detailed textual analysis.

Selected parts of English news stories and their Arabic translations are analyzed within the framework of the two theories. The analysis covers the lexical choices of the text producers/reproducers (i.e. writers/translators), and the narratives that are implied and intended to promote for the ideologies of the text producers or the institutions they represent. However, as Fairclough (2003) recommends, the analysis of the texts is not done as two separate stages, but rather as a simultaneous process where socionarrative analysis complements textual analysis. This is because although the two stages seem separable, the interaction between them is necessary for full analysis of the text.

\section{Data}

The data for this study are collected from a number of news stories published on electronic versions of some newspapers and news websites in both English and Arabic. English news articles were selected from a number of electronic news outlets, including Reuters, BBC, Washington Post, and The Daily Telegraph, and compared with their Arabic translations posted on a number of governmental or pro-governmental Arabic websites, including Al Ahram, Al Wafd, Masrawy, and Youm7. The articles cover two incidents that took place in Egypt: the crash of a Russian plane in Sinia ( $31^{\text {st }}$ October, 2015) and the murder of an Italian student in Cairo (25 th January, 2016). Both incidents represent a type of what Harding (2012) calls "shared/collective narrative." That is, stories that are "constructed collectively... through either consensus or coercion" ( $p$. 292). Moreover, the examples fall under the category of local narratives, since 
they are related to specific events that took place at specific times and specific places. The analysis focuses on the way the ideologically-loaded lexical items employed in these articles are translated into Arabic.

\section{Data Analysis}

\section{The Plane Crash: Guilty vs. Victim Narrative}

Example (1)

Russian and Egyptian officials are not to be trusted over airline crash... the Sissi and Putin regimes were focused on defending themselves

(The Washington Post, 2015 November 6)

انتقدت صحيفة الو اشنطن بوست في مقالتها الافتتاحية اليوم أنه لا يمكن الوثوق بكلا الحكومتين المصرية

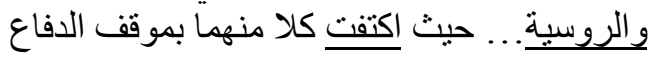

(Masrawy, 2015 November 7)

The Washington Post refers to the Egyptian and Russian governments using the last names of their presidents in an attempt to imply the dictatorship and the oneman state ruling system of both countries. The translator avoids delivering such a message by translating "the Sissi and Putin regimes" into “ الحكومتين المصرية "و الروسية. Understatement is achieved in this example by replacing the names of the presidents with the adjectives that refer to the nationalities of the governments.

Furthermore, by using the verb "focused" (ركزت), the English text implies that the two governments do not care about investigating the plane crash as much as they care about denying the media accusations. And while this meaning is partly comprehended from "اكتفت", this Arabic verb implies that they simply did not play an active role in the investigations, and not the intended meaning that defending their stances was the central point of their attention other than anything else.

Example (2)

BOMBING an airliner out of the sky would be a major step up in capabilities... for the two men who have built the forces of jihad in Egypt's Sinai Peninsula into a major threat.

(The Daily Telegraph, 2015 November 9)

أن تفجير طائرة الركاب الروسية فى الجو قد يعد بمثابة تقدم لقدرات تنظيم "الدولة الإسلامية،" مرجحين

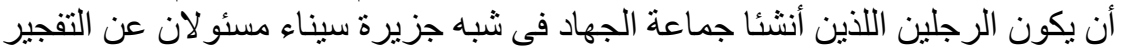

(Youm7, 2015 November 11) 
This example shows how deleting one or more lexical items can undermine the effect of the original narrative. The Arabic translation, which was published on the website of the Egyptian Information Authority, does not include the last phrase in the original English text "major threat," probably in order to underestimate the enemy and conform with the ideology espoused by the local media that Egypt can defeat such terrorist acts, and to foster the narrative that Egypt, though the victim in this case, is a powerful country.

\section{Example (3)}

Resisting Bomb Theory, Egypt Finds Itself Increasingly Alone

(The New York Times, 2015, November 6)

(Masrawy, 2015 November 7)

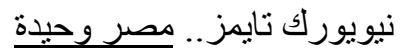

The English headline says that Egypt is the only country that is against the idea that the plane was bombed by terrorists while the translator deletes part of this headline to say مصر وحيدة (Egypt is lonely) to depict Egypt as a victim to a conspiracy organized by western media. The English text presents the narrative that Egypt is denying what seems to be a fact for everyone, while the Arabic translation re-frames the news within the conspiracy theory. According to Koehler-Derrick, Nielsen and Romney (2017), this theory is dominant in most Egyptian news outlets especially those supporting the government.

\section{Regeni Death: Murder vs. Incident Narrative}

Below are four examples taken from an opinion article by Calogero Nicosia entitled "Who is really behind Giulio Regeni murder in Egypt" published on the Canadian Geopolitical Monitor website. The article tackles the murder of Regeni, an Italian student who was studying in Egypt, opposing the claims that the student was killed by the Egyptian authorities. Parts of this article were translated and published on Al Wafd newspaper website under the title " ليياوتركيا " كلمة السر في مقتل الطالب الإيطالي بكصر by Lamees El Sharkawy on March 30, 2016. The translator manages to reframe the whole news article from the very beginning through inserting the names of the two countries Libya and Turkey in the headline as the perpetrators of the crime although the English headline is ambiguous.

Example (4)

... the idea that Regeni was killed by the Egyptian regime of Al-Sisi is ... quite illogical 
(Canadian Geopolitical Monitor, 2016 March 28)

إنه من غير المنطقي افتراض أن نظام الرئيس المصري عبد الفتاح السيسي له مصلحة في قتل الطالب

(Al Wafd, 2016 March 30)

The writer of the original text uses the verb "kill" to describe the incident of Regeni's death. The translator, on the other hand, replaces this lexical item with " which literally in English means (could benefit from), in an attempt to undermine the shocking effect of the literal equivalent "قتل on the target language reader. Moreover, "the Egyptian regime of Al-Sisi" is rendered as "نظام "الرثي "الرئيس المصري". The translator adds the phrase" الرئيس المصري عبد الفتاح السيسي "The "الري Egyptian President) to stress the legitimacy of Mr. El Sisi in an attempt to refute some western media's claims that he took over the presidency after a military coup.

\section{Example (5)}

Giulio has been killed because his research shed light on the brutality of the Al$\underline{\text { Sisi regime }}$

عدة دو افع لمقتل ريجيني ظهرت بعد الحادث كان على رأسها بحث الطالب الذى كان يناقش عنف النظام (Al Wafd, 2016 March 30)

The lexical item "brutality" is undermined by using the less shocking lexical item "وحنف "وحية" " (violence) instead of the literal translation". While both" and refer to the use of physical force, the latter denotes its use in a more excessive or savage manner. Moreover, "has been killed" is paraphrased into longer, less forceful translation in Arabic as "عدة دو افع لمقتل ريجيني".

Example (6)

... creates friction between Italy and Egypt...

(Canadian Geopolitical Monitor, 2016 March 28)

(Al Wafd, 2016 March 30)

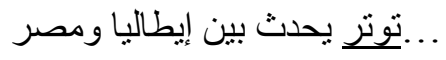

The writer of the original text believes that the murder was committed by Muslim Brotherhood to create "friction" between Egypt and Italy. According to Oxford Dictionary website, the lexical item "friction" means "conflict or animosity 
caused by a clash of wills, temperaments, or opinions" (2017). The translator understates this idea by rendering "friction" into "تونر" which literally means (tension) rather than the literal equivalent "خلاف". While both "friction" and "tension" refer to instability in the relationships between the two countries, the former conveys a higher level of disagreement than the latter which simply denotes strained political relationships.

Example (7)

... his [Regeni's] murder is the first time such an act has happened to a foreign academic researcher working in Cairo

(Canadian Geopolitical Monitor, 2016 March 28)

(Al Wafd, 2016 March 30)

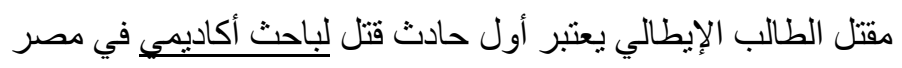

This is another example where deletion is resorted to by the translator in an attempt to understate what is being suggested by the source text. The lexical item "foreign" has disappeared from the translation to suggest that this is the first incident of its kind in Egypt for a researcher whether Egyptian or foreigner. Such deletion keeps the idea of targeting a human rights activist away from the reader's mind.

Example (8)

Whilst it [Foreign and Commonwealth Office] did express that these [allegations] indeed were 'unproven', it also elaborated that every possible scenario should be explored.

(The Tab Cambridge, 2016 April 26)

و أضاف البيان أنه رغم أن المز اعم بأن قوات الأمن المصرية كانت ور اءه مقتل الطالب "لم تتبت صحتها" إلا أنها "تدعو السلطات المصرية إلى در اسة كل السيناريو هات النئ أثناء التحقيق".

(Shorouk News, 2016 April 26)

This article entitled "UK government FINALLY responds to the murder of Giulio Regeni" comments on a statement issued by the UK government on the murder of Regeni. The statement implies that the allegations that the Italian student was killed by the Egyptian authorities, though not proven, should be taken into consideration. However, the translation delivers a different message. By adding "تندعو السلطات المصرية", the translator manages to change the role played by the Egyptian authorities from "the accused" to "the investigator." That is, according to the translation, the statement does no criticize the Egyptian 
authorities, but rather it advises them to look deeper into various possible "scenarios." This example shows that understatement can be achieved not only by deleting part of a message or substituting it with a milder way of expression, but also by inserting additional lexical items that can help change the narrative intended by the original text's producer.

Example (9)

... with Rome unwilling to jeopardize commercial ties over the brutal murder

(Reuters, 2016, April 12)

(Zahret El Tahrir, 2016 April 12)

لاتر غب روما في تعريض علاقتها التجارية مع مصر للخطر بسبب هذا الحادث

The phrase "brutal murder" is replaced by the more neutral, milder lexical item "الحادث" (incident) probably to conform with the ideology of the newspaper which is one of Egypt's pro-governmental websites, and to reframe Regeni's story as an "incident" rather than a "murder."

\section{Discussion}

The findings of the study reveal how ideological considerations can influence the translation of news stories. In the cited examples, the translators manage to change the narrative of the source text by manipulating the narrative elements, mainly the events and the actors. This manipulation is achieved through the technique of understatement. Some English lexical items are deleted or rendered into less-provoking Arabic equivalents in an attempt to reframe the events. While the plane crash is narrated by the English texts as a terrorist act that resulted from the inefficiency of Egyptian security measures, it is reframed as part of the Muslim Brotherhood's conspiracy to take revenge upon the Egyptian government. Similarly, Regeni's death is represented by western media as a murder committed by "Al Sisi regime," while the Arabic articles re-narrate it as an accidental death. These findings agree with the argument of Darwish (2006) and Liu (2013) that news translation is influenced by the ideology of the agencies that the translators belong to, and that it involves reshaping of events. This means that translators of such texts, as Doorslaer (2010) and Chen (2011) point out, filter the information of the source text before they start their task.

The results also show that understatement is not achieved only through replacing lexical items with less shocking equivalents in the other language. Deleting or inserting some words are also used in the discussed examples in order to avoid promoting for a competing narrative. It seems that the choice of the strategy adopted to underestimate a certain way of expression is not systematic. It does not depend on factors other than the translator's preferences, 
and more importantly, the internal relations of the text (i.e. the semantic, grammatical and lexical aspects). These relations help the translator to determine the kind of change (be it addition, omission or substitution) that can be made. This change should later be checked against the events that the text is representing in the real world and the ideology that the media institution releasing the translated news item desires to promote for. This proves the point made by Schaffner (2012) that news translation is "a textual and a sociocultural process" (p. 881).

Moreover, the findings go in line with Harding's (2012) view that news narratives can be manipulated by translators to promote for different narratives. This is clearly shown in the cited examples where the original English texts and their Arabic translations cover the same events and refer to the same actors, yet they differ in the way they shape the public understanding (i.e., their narratives). This difference is signaled through the use of vocabulary to serve the purpose of the texts' producers (be them narrators or temporary narrators).

Furthermore, the data bring up to the surface the importance of combining more than one approach to analyze the way media institutions can win over their audience. While textual analysis alone can explain the linguistic decisions made by the text producer (be it a writer or a translator), it falls short of linking the ideology expressed by such linguistic decisions to its socionarrative context. Therefore, to analyze news translation, there is a need for a transdisciplinary approach that explains how translators' lexical choices are prompted by ideological consideration to promote for certain narratives.

The results, thus, prove the hypothesis of the study that understatement is a tool that is used by news producers (whether writers or translators) to promote for narratives that reflect the ideology of the media institutions they are work at. A systematic analysis of news translations, therefore, requires a transdisciplinary approach that allows examining texts textually and intratexually.

\section{Conclusion}

World events are subject to manipulation by news writers and translators. In most cases, the language used in reporting/translating news is far from being neutral; lexical choices are made and translation strategies are used to serve the interest of one group or institution over the other, and to reflect certain ideologies and narratives. In most cases, when a news story is translated into a competing culture, it brings into conflict two distinct narratives and ideologies. Therefore, the translation of news stories involves modifications that may take the form of addition, omission, or substitution. These modifications are dictated by the ideology of the institution that publishes the translated news. This has led to the emergence of the term "transeditors" and the newly coined term "journalator" to 
refer to news translators. Understatement is one of the techniques used by translators to change the narrative of news. Deleting, adding, or replacing some lexical items are all possible strategies that translators may adopt to understate the message of the original text. Such understatement is usually reflected in the narrative suggested by source language text's producers (which again is probably prompted by the media institution they are part of). In the examples analysed above, a different competing narrative is promoted for by the translator through using less shocking modes of expression.

This study thus shows how translators of Egyptian pro-government online media outlets use understatement to re-frame political events and, thus, undermine the opposing narrative or, even, circulate a different, probably competing narrative. The examples discussed show how ideologies of media institutions influence the production and translation of news stories. Ideologies force both the writer and the translator of a given news story to make certain lexical choices promoting certain narratives that go in line with their institutions' ideologies. More often than not, the source text and its translation cover the same events, yet they differ in the way they shape the public understanding of these events.

Finally, it is to be noted that the advantage of integrating CDA with a Socionarrative Approach is that it can take us beyond the textual analysis, bringing an additional dimension into focus. Texts are no longer viewed as choices dictated by the nature of the language in use, but rather as intentional decisions made by participants involved in a social interaction (i.e. translation). It is believed that such an approach can explain and justify the strategies that translators use when dealing with news stories, and highlight translators' role as active key participants in the communication process.

\section{Definitions of Terms}

Term

Framing

Ideology

Ideology-loaded lexical items

\section{Definition}

The key concept within the framework of Baker's (2006) Narrative Theory and Harding's (2012) Socionarrative Theory, referring to a number of techniques that people use to narrate the same event in different ways.

A social theme that is not merely related to attitudes and beliefs, but is also about power and supremacy (Fairclough, 2003).

Words or phrases that implicitly or explicitly establish a certain ideology. 
Narrative Theory A theory developed by Baker (2006), suggesting that people usually narrate events from their own points of view using framing techniques.

Narrators

News translation

Relational Approach

Socionarrative Theory

Temporary narrators

Transdisciplinary approach

Understatement
A term used in Harding's (2012) Socionarrative Theory to refer to original producers of news articles.

The translation of online and printed news articles.

An approach suggested by Fairclough (2003) that views texts as combinations of internal and external relations. The former refer to the semantic, lexical, grammatical and phonological choices, whereas the latter are related to how much of the world the texts reflect and how they represent that world.

A theory developed by Harding (2012) where narrataology and sociology are integrated to analyse texts intratextually.

A term used in Harding's (2012) Socionarrative Theory to refer to translators of news articles who are thought to contribute to reframing the source texts.

An approach that links theories and concepts from two or more disciplines. In this study the link is established between Critical Discourse Analysis and Translation Studies.

Translating an ideology-loaded lexical item in a way that can make a certain event seem less important, serious or shocking than it is believed to be.

\section{References}

Baker, M. (2006). Translation and conflict: A narrative account. London: Routledge.

Bal, M. (2009). Narratology: An introduction to the theory of narrative. Toronto: University of Toronto Press.

Calzada-Pérez, M. (2003).Introduction. In M. Calzada-Pérez (Ed.) Apropos of ideology (pp. 1-22).Manchester: St. Jerome.

Chen, Y. (2011). The translator's subjectivity and its constraints in news transediting: A perspective of reception aesthetics." Meta, LVI (1): 119-144.

Cheng, F. (2012). Connection between news narrative discourse and ideologybased on narrative perspective analysis of "News Probe". Asian Social Science, 8(12). Retrieved from http://www.ccsenet.org/ journal/index.php/ass/article/view/20761 
Darwish, A. (2006). Translating the news reframing constructed realities. Translation Watch Quarterly, 2(1), 52-94.

Fairclough, N. (2003). Analyzing discourse: Textual analysis for social research. London/: Routledge.

Friction. (2017). Oxford Living Dictionaries. Retrieved from https://en.oxforddictionaries.com/definition/friction

Harding, S. (2012). How do I apply narrative theory? Socio-narrative theory in translation studies. Target, 24(2), 286-309.

Haj Omar, H. (2016). Ideology, media and conflict in political discourse and its translation during the Arab Spring: Syria as a case study. $\mathrm{PhD}$ thesis, University of Leeds. Retrieved from http://etheses.whiterose.ac.uk/ 15193/1/PhD\%20thesis\%20-\%20revised.pdf

Hatim, B., \& Mason, I. (1997). The Translator as Communicator. London: Routledge.

Koehler-Derrick, G., Nielsen, R., \& Romney, D. (2017). Conspiracy theories in the Egyptian state-controlled press. Retrieved from http://aalims.org/uploads/conspiracy_10april2017_AALIMS.pdf

Lefevere, A. (1998). Translation practice(s) and the circulation of cultural capital: Some aeneids in English. In S. Bassnett \& A. Lefevere (Ed.) Constructing cultures: Essays on literary translation (pp. 41-56). Clevedon: Mutlilingual Matters.

Liu, N. (2013). News translation as reconstruction of reality within frames, presented at the FIT 7th Asian Translators' Forum. Penang, Malaysia 27-29th 2013. Retrieved from http://translationjournal.net/Featured-Article/newstranslation-as-reconstruction-of-reality-within-frames.html

Schäffner, C. (2012). Rethinking transediting. Meta, 57(4), 866-883.

Thompson, J. (1984). Studies in the theory of ideology. Berkeley: University of California.

Understatement. (2017). Cambridge Dictionary. Retrieved from http://dictionary.cambridge.org/dictionary/english/understatement

Understatement. (2017). Literary Devices: Definition and examples of literary terms. https://literarydevices.net/understatement/

Van Dijk, T. (1993). Principles of critical discourse analysis. Discourse and society, 4(1), $249-283$.

Van Dijk, T. (2003). Ideology and discourse: A multidisciplinary introduction. Retrieved from http://www.discourses.org/download/ articles/

Van Doorslaer, L. (2010). Journalism and translation. In Y. Gambier \& L. Van Doorslaer (Eds.) Handbook of translation studies (pp. 180-184). Amsterdam: John Benjamins. 
Van Doorslaer, L. (2012). Translating, narrating, and constructing images in journalism, with a test case on representation in Flemish TV news. Meta, 57(4), 1046-1049.

Van Dijk, T. (2015).Critical discourse analysis. In D. Tannen, H. Hamilton \& D. Schiffrin (Eds.) The handbook of discourse analysis (pp466- 485). John Wiley \& Sons. 352-371.

Wodak, R. \& Meyer M. (2008).Critical discourse analysis: History, agenda, theory, and methodology. Retrieved from http://www.miguelangel martinez.net/IMG/pdf/2008_Wodak_Critical_Discourse_Analysis_Ch_01.p df

\section{Online Articles}

Arafa, A. (2015, November 11). هيئة الاستعلامات" تنشر تناول وسائل الإعلام الغربية لحادثة هoum7. Retrieved from http://www.youm7.com/ story/2015/11/11/

Balmer, C. (2016, April 12). Few options for Italy as it pressures Egypt over murdered student. Reuters. Retrieved fromhttp://www.reuters.com/ article/us-egypt-italian-pressure-idUSKCN0X91VI

Dawson, H. (2016, April 26). UK government FINALLY responds to the murder of Giulio Regeni. The Tab Cambridge. Retrieved from http://thetab.com/uk/cambridge/2016/04/26/uk-gov-responds-giulio-regenimurder-74655

Editorial Board. (2015, November 6). Russian and Egyptian officials are not to be trusted over airline crash. Washington Post. Retrieved fromhttps://www.washingtonpost.com/opinions/obfuscation-in-the-sinaivalley/2015/11/06/a7e5aa74-84ab-11e5-9afb 0c971f713d0c_story.html

خditorial Board. (2016, April 12). خيار ات إيطاليا محدودة في الضغط على مصر بشأن مقتل Zahrt Eltahrir. Retrieved from http://zahrteltahrir.net

Editorial Board. (2016, April 26) بريطانيا تعرب عن 》خيبة أملهي بشأن سير التحقيق في مقتل

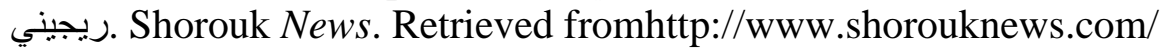

El Sharkawy, L. (2016, March 30). ليبياوتركيا كلمة السر في مقتل الطالب الإيطالي بمصر. Al Wafd Retrieved from http://alwafd.org/

هل تخاذل الإعلام المصري في حادث . El Fouly, D. and Salama, Y. (2015, November 7) هل Masrawy. Retrieved from http://www.masrawy.com/ News/News_Various/details/2015/11/7

Kirkpatrick, D. (2015, November 6). Resisting bomb theory, Egypt finds itself increasingly alone. The New York Times. Retrieved from http://www.nytimes.com/2015/11/07/world/middleeast/egypt-russian-planecrash-investigation.html?_r=0 
Nicosia, C. (2016, March 28). Who is really behind Giulio Regenis murder in Egypt? The Canadian Geopolitical Monitor. Retrieved from https://www.geopoliticalmonitor.com/who-is-really-behind-giulio-regenismurder-in-egypt/.

Spencer, R. (2015, November 9). Obscure jihadists who claim to have brought down plane. The Daily Telegraph. Retrieved from http://www.pressreader.com/ 